\title{
Does Monocyte Distribution Width (MDW) Have Prognostic Value in Acute Pancreatitis?
}

\section{Akut Pankreatitte Monosit Dağıtım Genişliğinin (MDW) Prognostik Değeri Var Mıdır? Bir Ön Çalışma}

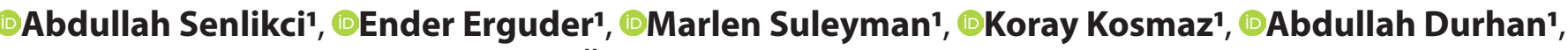

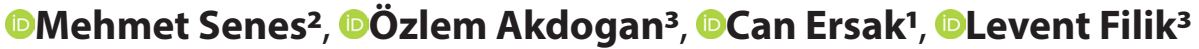

'Ankara Training and Research Hospital, General Surgery Department, Ankara, Turkey

${ }^{2}$ Ankara Training and Research Hospital, Biochemistry Department, Ankara, Turkey

${ }^{3}$ Ankara Training and Research Hospital, Gastroenterology Department, Ankara, Turkey

\begin{abstract}
Aim: Acute pancreatitis is a common disease that can be fatal at advanced stages. Therefore, early evaluation of the prognosis of acute pancreatitis is important. The aim of this study was to evaluate the importance of monocyte distribution width in defining the prognosis of acute pancreatitis.

Material and Method: The study included patients hospitalized with the diagnosis of acute biliary pancreatitis between December 2019 and October 2020. The cases were evaluated in 2 groups as mild pancreatitis and non-mild pancreatitis. The groups were compared in terms of age, white blood cell, neutrophil count, C-reactive protein, length of hospital stay, neutrophil to lymphocyte ratio, Monocyte Distribution Width, amylase, Aspartate Aminotransferase, albumin, and lactate dehydrogenase.

Results: A statistically significant difference was determined between the mild pancreatitis group (n:59) and non-mild pancreatitis group $(n: 48)$ in terms of white blood cell, neutrophil count, C-reactive protein, Monocyte Distribution Width and length of hospital stay $(p<0.05)$. When the cut-off value for Monocyte Distribution Width was taken as 703.00 , sensitivity was $50.94 \%$ and specificity was $61.11 \%$.

Conclusion: The Monocyte Distribution Width is a parameter that can be used to differentiate mild pancreatitis from non-mild pancreatitis. More extensive studies are needed for a clearer evaluation.
\end{abstract}

Keywords: Acute pancreatitis, monocyte distribution width, prognosis
Öz

Amaç: Akut pankreatit, ileri evrelerde ölümcül olabilen yaygın bir hastalıktır. Bu nedenle, akut pankreatit prognozunun erken değerlendirilmesi önemlidir. Bu çalışmanın amacı, akut pankreatit prognozunun tanımlanmasında monosit dağılım genişliğinin önemini değerlendirmektir.

Gereç ve Yöntem: Çalışmaya Aralık 2019 ile Ekim 2020 arasında akut biliyer pankreatit tanısıyla hastaneye yatırılan hastalar dahil edildi. Olgular hafif pankreatit ve hafif olmayan pankreatit olarak 2 grupta değerlendirildi. Gruplar yaş, beyaz küre sayısı, nötrofil sayısı, C-reaktif protein, hastanede kalış süresi, nötrofil/lenfosit oranı, monosit dağılım genişliği, amilaz, aspartat aminotransferaz, albümin ve laktat dehidrojenaz açısından karşılaştırıldı.

Results: Hafif pankreatit grubu (n: 59) ve hafif olmayan pankreatit grubu (n: 48) arasında beyaz küre sayısı, nötrofil sayısı, C-reaktif protein, Monosit Dağılımı Genişliği ve hastanede kalış süresi açısından istatistiksel olarak anlamlı fark belirlendi $(p<0.05)$. Monosit Dağılım Genişliği için cut-off değeri 703.00 olarak alındığında, duyarlılık \%50.94 ve özgüllük \%61.11 idi.

Sonuç: Monosit Dağılım Genişliği değeri, hafif pankreatiti hafif olmayan pankreatitten ayırt etmek için kullanılabilen bir parametredir. Daha net bir değerlendirme için daha kapsamlı çalışmalara ihtiyaç vardır.

Anahtar Kelimeler: Akut pankreatit, monosit dağılım genişliği, prognoz 


\section{INTRODUCTION}

Acute pancreatitis (AP) is a common, non-bacterial disease that occurs with the development of widespread inflammation as a result of the automatic digestion of pancreatic and surrounding tissue by normally inactive pancreatic enzymes. ${ }^{[1]}$ History and examination can be indicative of AP, and two of the following three criteria should be met for diagnosis: typical history, elevated serum amylase or lipase ( $\geq 3$-fold more than the upper limit), imaging (computed tomography, magnetic rezonanas imaging or ultrasound) consistent with acute pancreatitis. ${ }^{[2]}$ Some classification systems have started to be used in recent years, and one of the most widely used is the Atlanta classification system. According to the revised Atlanta classification in 2012, severe acute pancreatitis (SAP) is defined as an episode of pancreatitis with persistent organ failure. This situation has been reported to have a mortality rate of $12 \%$ in patients with sterile necrosis, 30\% in those with infected necrosis and $47 \%$ in those with multiple organ failure (MOF). Therefore, early assessment of the severity of AP and adequate treatment are of the utmost importance. ${ }^{[3]}$ Hematological biomarkers, such as blood cell indices, have been explored in recent years for their potential role in predicting subsequent septic episodes in at-risk patients. In particular, preliminary evidence has been collected on the possible relevance of Monocyte Distribution Width (MDW). ${ }^{[4]}$ A feasibility study recently conducted at a single academic center showed that acute changes in monocyte size, referred to as the monocyte distribution width (MDW), best discriminated sepsis (e.g., compared with neutrophil volume changes) from other acute illnesses in the emergency department and further suggested that the combined performance of MDW and white blood count (WBC) for early sepsis detection was superior to either MDW or WBC alone. ${ }^{[5]}$

In the light of these studies on the determination of sepsis severity, the aim of this retrospective study was to evaluate whether Monocyte Distribution Width (MDW) may play a role in identifying patients with acute pancreatitis.

\section{MATERIAL AND METHOD}

This retrospective study included 107 patients who had been diagnosed with acute biliary pancreatitis between December 2019 and October 2020. The study was approved by the Local Ethics Committee (decision no: 481, date: 10/12/2020). Written informed consent was not necessary because no patient data has been included in the manuscript. All patients were diagnosed on the basis of epigastric pain or abdominal tenderness to palpation on physical examination together with elevation in plasma amylase to $\geq 3$-fold more than the upper limit of normal and characteristic radiological findings of the disease with ultrasonography and/or abdominal computed tomography (CT). AP was categorized according to the Atlanta criteria as mild, moderate or severe depending on the presence of organ failure for more than 48 hours or local complications.
Descriptive, demographic, radiographic and laboratory data were obtained from T.C. H. S. U. Ankara Research and Training Hospital medical records. All laboratory measurements on the first complete blood count before hospitalization were analyzed. All diagnostic and research parameters in the blood count results of the samples were evaluated using the XN-1000 (Sysmex, Kobe, Japan) blood count system. Biochemistrical research parameters were obtained from Roche Cobas 6000 (Roche, Germany) analyzer system. Datas were evaluated in hour after blood samples were taken and patients with incomplete datas were excluded from the study.

Sysmex blood count systems, evaluates 3 separate signals for each cell in identifying and counting leukocyte subpopulations with the fluorescent flow cytometry technology. These signals refer to the cells: size, scattered light, and fluorescent retention capacity. The increase in fluorescence retention capacity measured by fluorescent markers specific for DNA and RNA, which are intracellular genetic materials, is associated with the reactivity status, as it reflects changes in the direct metabolic activity of the analized cell population. Likewise, changes in cell size and scattered light signals provide morphological information to help us evaluate the reactivity of cells. It has been demonstrated that monocytes increase in size upon activation in bacteremic patients, and that this infection-related variation in size may be easily monitored by measuring the spread of monocytes in counters.

The cases were separated into two groups as mild pancreatitis and moderate-severe pancreatitis. The groups were compared in terms of age, WBC, neutrophil count, C-reactive protein (CRP), length of hospital stay, neutrophil to lymphocyte ratio (NLR), MDW, amylase, Aspartate Aminotransferase (AST), albumin, and lactate dehydrogenase (LDH). ROC curve analysis was applied to the MDW value.

\section{Statistical Analysis}

The data obtained from the study were analyzed statistically using SPSS 22.0 software (IBM Corpn, Armonk, NY, USA). Categorical measurements were recorded as number and continuous data as mean and standard deviation values. Normal distribution of continuous variables was evaluated with the ShapiroWilk test. Non-parametrically distributed numerical data were stated as median (IQR). In the comparisons between the groups, the Student's t-test was applied to parameters with normal distribution and the Mann-Whitney U-test to parameters not showing normal distribution. Sensitivity, specificity positive predictive value (PPV) and negative predictive value (NPV) values were calculated by calculating the area under the ROC curve to determine whether the measurements of MDW were effective in differentiating mild pancreatitis from moderate and severe pancreatitis. A value of $p<0.05$ was considered statistically significant. 


\section{RESULTS}

Evaluation was made of a total of 107 patients, comprising 35 men and 72 women. There were 59 patients in the mild pancreatitis group (Group 1) and 48 patients in the moderate and severe pancreatitis group (Group 2). The mean age of the patients was 57.78 years in Group 1 and 58.42 years in Group 2 . The differences between the groups between wbc, neutrophil count, CRP, length of stay, NLR, monocyte distribution width, amylase, AST, albumin, LDH are evaluated in Table 1. The mean WBC, neutrophil count, CRP, MDW and length of stay in hospital values were statistically significantly lower in Group 1 than in Group 2.

ROC curve analysis was performed using MDW variable to differentiate cases of mild pancreatitis (Group 1) from moderate and severe pancreatitis (Group 2). In the ROC curve analysis, the area under curve (AUC) was 0.618 for MDW. Sensitivity was $50.94 \%$ and specificity was $61.11 \%$ when the cut-off value for MDW was taken as 703 (Figure 1, Table 2).

\section{DISCUSSION}

From the results of the study it was concluded that the increase in white blood cell count, neutrophil count, MDW and CRP are associated with moderate to severe pancreatitis.

WBC has long been used as an infection and inflammation biomarker. The WBC value is used in some scoring systems such as APACHE-II and Ranson criteria to evaluate the prognosis of acute pancreatitis. ${ }^{[6]}$ In a study by Yarkaç et al. $^{[7]}$ it was concluded that the WBC value can be used both in the diagnosis of acute pancreatitis and for the differentiaton of mild and severe pancreatitis. Huang et al. ${ }^{[8]}$ also demonstrated that the WBC value can be used to distinguish between mild and severe pancreatitis.In the current study, it was concluded that the WBC value is the most sensitive and specific marker that can be used to differentiate mild and moderate-severe pancreatitis.

An increase in neutrophil count indicates the development of systemic inflammatory response syndrome (SIRS) and multiple organ failure, and this is an indicator of severe pancreatitis. Neutrophils provoke an inflammatory cascade and SIRS in AP, causing an increase in lymphocyte count during severe sepsis, and this is associated with a poor prognosis. ${ }^{[9]}$ In the current study, it was concluded that neutrophil count can be used to distinguish between mild and moderate-severe pancreatitis. In the study by Han et al. ${ }^{[10]}$ it was concluded that NLR is an early predictor in the diagnosis of severe pancreatitis. Suppiah et al.. ${ }^{[1]}$ also

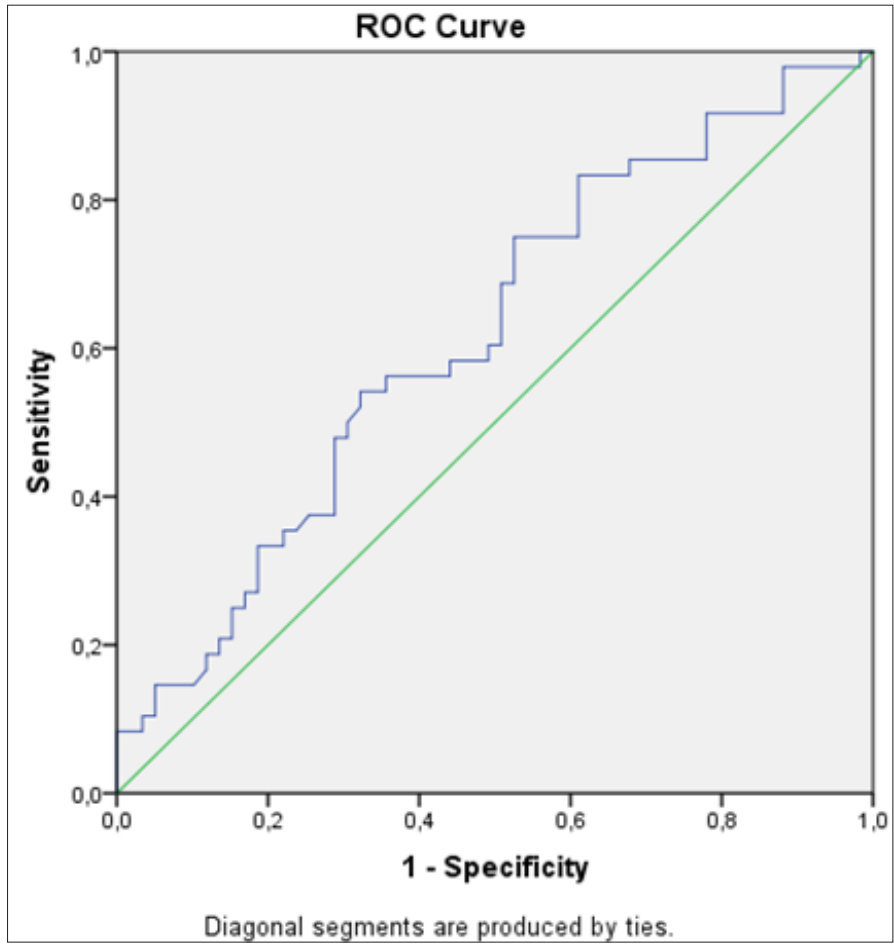

Figure 1. Graph of ROC Curve Analysis for monocyte distrubition width

Table 1. Comparison of parameters between Atlanta 1-Atlanta 2 and 3

\begin{tabular}{|c|c|c|c|}
\hline & $\begin{array}{c}\text { Group } 1 \text { (Atlanta } \\
\text { 1) (59) }\end{array}$ & $\begin{array}{c}\text { Group } \\
2-3)(48)\end{array}$ & $\mathbf{P}$ \\
\hline Age & $\begin{array}{l}57.78 \\
( \pm 19)\end{array}$ & $\begin{array}{l}58.42 \\
( \pm 17)\end{array}$ & 0.857 \\
\hline Wbc $(\mu \mathrm{L})$ & $\begin{array}{c}11374 \\
( \pm 3340)\end{array}$ & $\begin{array}{c}14166 \\
( \pm 5085)\end{array}$ & $0.001^{*}$ \\
\hline Neutrophil count $(\mu \mathrm{L})$ & $\begin{array}{c}9016 \\
( \pm 3163)\end{array}$ & $\begin{array}{c}11582 \\
( \pm 5207)\end{array}$ & $0.002^{*}$ \\
\hline $\mathrm{CRP}(\mathrm{mg} / \mathrm{L})$ & $\begin{array}{l}28.16 \\
( \pm 43)\end{array}$ & $\begin{array}{l}58,1985 \\
( \pm 79)\end{array}$ & $0.014^{*}$ \\
\hline Length of stay (Days) & $\begin{array}{l}3.63 \\
( \pm 2)\end{array}$ & $\begin{array}{l}6.73 \\
( \pm 4)\end{array}$ & $<0.001^{*}$ \\
\hline NLR & $\begin{array}{l}8.45 \\
( \pm 8)\end{array}$ & $\begin{array}{l}11.65 \\
( \pm 11)\end{array}$ & 0.107 \\
\hline $\begin{array}{l}\text { Monocyte } \\
\text { distribution width }\end{array}$ & $\begin{array}{l}697.5 \\
( \pm 93)\end{array}$ & $\begin{array}{l}738.8 \\
( \pm 101)\end{array}$ & $0.028 *$ \\
\hline Amilase (IU/L) & $\begin{array}{c}1587.66 \\
( \pm 835)\end{array}$ & $\begin{array}{c}1744,31 \\
( \pm 881)\end{array}$ & 0.349 \\
\hline AST (IU/L) & $\begin{array}{l}192.07 \\
( \pm 169)\end{array}$ & $\begin{array}{l}242.96 \\
( \pm 254)\end{array}$ & 0.219 \\
\hline Albumin (g/dL) & $\begin{array}{c}42.40 \\
( \pm 4)\end{array}$ & $\begin{array}{c}40.98 \\
( \pm 5)\end{array}$ & 0.152 \\
\hline LDH (U/L) & $\begin{array}{l}358.90 \\
( \pm 144)\end{array}$ & $\begin{array}{l}536.15 \\
( \pm 920)\end{array}$ & 0.148 \\
\hline
\end{tabular}

Table 2. Sensitivity, specificity, positive predictive value and negative predictive value of Monocyte distribution width

\begin{tabular}{|c|c|c|c|c|c|}
\hline Cut-off & Area Under Curve & Sensitivity (95\% CI) & Specificity (95\% CI) & PPV (95\% Cl) & NPV $(95 \%$ CI) \\
\hline 703 & 0.618 & $50.94(36.84-64.94)$ & $61.11(46.88-74.08)$ & $56.25(45.64-66.32)$ & $55.93(47.28-64.24)$ \\
\hline
\end{tabular}


found that elevated NLR in the first 48 hours is a sign of severe pancreatitis and is an independent negative prognostic factor. From the results of the current study, it was concluded that NLR can't be used to differentiate mild and severe pancreatitis.

C-reactive protein half-life is an important factor in evaluating acute response due to its short duration. CRP levels are generally used in patients with pancreatitis at the time of admission and during treatment. ${ }^{[12]}$ Liang et al. ${ }^{[13]}$ concluded that CRP can be used in the diagnosis of acute pancreatitis and in evaluating the prognosis of severe pancreatitis. The study by Staubli et al. ${ }^{[14]}$ showed that CRP can be used in systemic inflammatory response syndrome and to predict mortality.In the current study, it was concluded that CRP could be used in the differentiation of mild and non-mild pancreatitis. As a negative acute phase reactant, albumin is associated with disease progression and sepsis. Hong et al. ${ }^{[15]}$ reported that low albumin levels increase the possibility of organ failure and death in acute pancreatitis. In the current study, the albumin value can't be used in the differentiation of mild and non-mild pancreatitis.

Circulating neutrophils and monocytes constitute the first response to pathogenic organisms. Recent studies have shown that increased immune cell volume may be used in the diagnosis of sepsis. Crouser et al. ${ }^{[16]}$, reported that the combined use of MDW and WBC can be used in the diagnosis of sepsis, and in another study by Crouser et al. ${ }^{[17]}$, it was concluded that MDW can be used in the early diagnosis of sepsis in the emergency department. In a recent study by Ognibene et al. ${ }^{[18]}$, it was reported that MDW can be used as a sepsis indicator in Covid-19 patients. In a study of Agnello et al. ${ }^{[19]}$, it was reported that MDW could be a reliable marker of sepsis in intensive care unit.In the current study, the utility of the MDW was evaluated in the differentiation of mild and non-mild pancreatitis. There was a statistically significant difference between mild and non-mild pancreatitis.

The limitations of this study are that it is a retrospective study and the number of patients is small. As it is a preliminary study, it could not be compared with healthy volunteers. New studies should be planned in the future by making larger studies and comparisons with the healthy control group.

\section{CONCLUSION}

WBC, neutrophil count, CRP, MDW values are parameters that can be used to differentiate mild pancreatitis from non-mild pancreatitis. The MDW value is a parameter that can be used to differentiate mild pancreatitis from non-mild pancreatitis, but this prelaminary study should be supported with further studies with more cases, for a clearer evaluation.

\section{ETHICAL DECLARATIONS}

Ethics Committee Approval: The study was approved by Ankara Training and Research Hospital Ethics Committee (decision no: 481, date: 10/12/2020).

Informed Consent: Because the study was designed retrospectively, no written informed consent form was obtained from patients

Referee Evaluation Process: Externally peer-reviewed.

Conflict of Interest Statement: The author(s) declared no potential conflicts of interest with respect to the research, authorship, and/or publication of this article.

Financial Disclosure: The authors declared that this study has received no financial support.

Author Contributions: Surgical and Medical Practices: MS, KK, AD ,OA, LF Concept: AS, EE Design: AS, EE Data Collection and Processing: EE,MeS,CE, Analysis and Interpretation: AS, EE, MS Literature Search: AS, AD, KK, OA Writing: AS, EE, MeS

\section{REFERENCES}

1. Durak, D., Senlikci, A., Dumlu, E.G. et al. Prognostic Significance of Thiol/ Disulfide Ratio in the Diagnosis of Acute Biliary Pancreatitis. Indian J Surg 2020. doi.org/10.1007/s12262-020-02510-6.

2. Goodchild G, Chouhan M, Johnson GJ. Practical guide to the management of acute pancreatitis. Frontline Gastroenterol. 2019;10(3):292-9.

3. Sebastian Manuel Staubli, Daniel Oertli \& Christian Andreas Nebiker Laboratory markers predicting severity of acute pancreatitis, Critical Reviews in Clinical Laboratory Sciences 2015;52(6):273-83.

4. Polilli E, Sozio F, Frattari A, et al. Comparison of Monocyte Distribution Width (MDW) and Procalcitonin for early recognition of sepsis. PLoS One. 2020;15(1):e0227300.

5. Crouser ED, Parrillo JE, Seymour CW, et al. Monocyte Distribution Width: A Novel Indicator of Sepsis-2 and Sepsis-3 in High-Risk Emergency Department Patients. Crit Care Med. 2019;47(8):1018-25.

6. Park HS, In SG, Yoon HJ, et al. Predictive values of neutrophil-lymphocyte ratio as an early indicator for severe acute pancreatitis in the emergency department patients. J Lab Physicians. 2019;11(3):259-64.

7. Yarkaç A, Kose A, Bozkurt Babuş S, et al. The value of hematological parameters in acute pancreatitis. Ulus Travma Acil Cerrahi Derg. 2019;25(5):453-60.

8. Huang L, Chen C, Yang L, et al. Neutrophil-to-lymphocyte ratio can specifically predict the severity of hypertriglyceridemia-induced acute pancreatitis compared with white blood cell. J Clin Lab Anal. 2019;33(4):e22839.

9. Kokulu K, Günaydın YK, Akıllı NB, et al. The Relationship between the neutrophil-to-lymphocyte ratio in acute pancreatitis and the severity and systemic complications of the disease. Turk J Gastroenterol 2018; 29: 68491.

10. Han C, Zeng J, Lin R, et al. The utility of neutrophil to lymphocyte ratio and fluid sequestration as an early predictor of severe acute pancreatitis. Sci Rep. 2017;7(1):10704.

11. Suppiah A, Malde D, Arab T, et al. The prognostic value of the neutrophillymphocyte ratio (NLR) in acute pancreatitis: identification of an optimal NLR. J Gastrointest Surg. 2013;17(4):675-81.

12. Kaplan M, Ates I, Akpinar MY, et al. Predictive value of C-reactive protein/ albumin ratio in acute pancreatitis. Hepatobiliary Pancreat Dis Int. 2017;16(4):424-30. 
13. Liang Y, Zhao X, Meng F. Procalcitonin, C-Reactive Protein, and Neutrophil Ratio Contribute to the Diagnosis and Prognosis of Severe Acute Pancreatitis. Iran J Public Health. 2019;48(12):2177-86.

14. Staubli SM, Schäfer J, Rosenthal R, et al. The role of CRP and Pentraxin 3 in the prediction of systemic inflammatory response syndrome and death in acute pancreatitis. Sci Rep. 2019;9(1):18340.

15. Hong W, Lin S, Zippi M, et al. Serum Albumin Is Independently Associated with Persistent Organ Failure in Acute Pancreatitis. Can J Gastroenterol Hepatol. 2017;5297143.

16. Crouser ED, Parrillo JE, Seymour C, et al. Improved Early Detection of Sepsis in the ED With a Novel Monocyte Distribution Width Biomarker. Chest. 2017;152(3):518-26.

17. Crouser ED, Parrillo JE, Martin GS, et al. Monocyte distribution width enhances early sepsis detection in the emergency department beyond SIRS and qSOFA. J Intensive Care. 2020;8:33.

18. Ognibene A, Lorubbio $M$, Magliocca $P$, et al. Elevated monocyte distribution width in COVID-19 patients: The contribution of the novel sepsis indicator.[published online ahead of print, 2020 Jun 3] Clin Chim Acta. 2020;509:22-4.

19. Agnello L, Sasso BL, Giglio RV, et al. Monocyte distribution width as a biomarker of sepsis in the intensive care unit: A pilot study. Ann Clin Biochem. 2021;58(1):70-3. 